\title{
A Conceptual Framework on the Corporate Social Responsibility Disclosure: Profitability, Leverage and Company Size
}

\author{
Noegrahini Lastiningsih, Ermawati \\ Universitas Pembangunan Nasional Veteran Jakarta, Indonesia \\ Noegrahini@gmail.com,ermawati@upnvj.ac.id
}

\begin{abstract}
This research begins with environmental damage is mostly carried out by companies with the background of company activities related to nature, and companies in Indonesia have not been able to carry out their social responsibilities to the society and the culture in which they operate to their full potential. This phenomenon also proves that the legal basis is not sufficient to motivate companies to carry out CSR as well as possible, but it also making social concerns a priority and part of the company's corporate plan needs engagement and support from management and shareholders. The aim of this research was to find out what factors influence corporate social responsibility disclosure on the Indonesian stock exchange. This study has three objectives namely to find out profitability, leverage and company size for corporate social responsibility disclosure. Therefore, this study relates to the measurement of corporate social responsibility disclosures by companies listed on the Indonesian stock exchange.
\end{abstract}

Keywords: CSR Disclosure, Profitability, Leverage, Company size.

\section{Introduction}

Today, the typical company report aims to not only clarify financial details but also to display and relay information about social and environmental issues (Rahman et al., 2011). It is referred to as a triple bottom line study because of the combination of these three reports. According to Gray (1987), this increase is estimated based on the assumption that companies are required to have broader responsibilities and not only generate material benefits for shareholders. The company had difficulty compiling this social responsibility report which made this a failure. The failure that companies experience in reporting problems is their inability to find a "reporting license" (Thomson and Zakaria, 2004). In Indonesia, there are many companies in the mining industry that cause environmental and social damage to society, both negative and positive. Examples such as the PT Batu Bara Bukit Asam (Persero) Tbk and PT Timah (Persero) Tbk has proven each performance assessment indicator and the average disclosures already exceed $75 \%$. However, the disclosure of indicators and their respective aspects is still not detailed. PT. Freeport, PT. Antam (Miscellaneous Mines) and PT. Valley. PT Vale is a nickel mining company located in Sorowako, South Sulawesi. The operation of the company resulted in negative impacts such as air pollution and water becoming cloudy. As a result, a few residents have complained about the water pollution. So that PT Vale must be responsible for the effect of the business operations. The corporate social responsibility report is intended as a corporate communication tool.

Marketing media is used by companies that allow stakeholders to assess legal aspects (Podnar and Golob, 2007; Nielsen and Thomsen, 2007). Therefore, the degree of corporate social responsibility. It is assumed that the company will disclose information to convey its meaning in calculating the corporate social responsibility program for society (Lone, Ali and Khan, 2016). Over the years, the number of companies reporting their social responsibility plans has increased (Salehi, Tarighi and Rezanezhad, 2019). Furthermore, at this time, the company was forced to remain competitive in the global market. Some methods to do the company can compete is by doing activities that are not only focused on providing benefits for the company, but also to provide benefits to the community and the surrounding environment. The components of society and the environment is linked closely interconnected with the company in carrying out its activities with members and need each other. The company must be able to understand that its responsibility is not only to shareholders, but more broadly, the company must be able to have a positive impact on the community and the surrounding environment so that one day the company will indirectly benefit from its concern for the environment. The positive influence that can be done by companies is by holding Corporate Social Responsibility (CSR) activities (Respati and Hadiprajitno, 2015). Friedman (1962) stated that the sustainability of a company is not only based on the profit aspect of the company but also must see the human element inside and outside the company (People) and the environment (Planet). 
A company or organization that can maintain its consistency is an organization that can manage these three elements to put into practice the company's operating activities. Problems in the social environment of the company can have an impact on difficulties for companies that are congested when operating, and can even lead to new complications, namely legal problems. So that, apart from entangling legal issues, the organization is required to engage in CSR for corporate responsibility and to ensure the company's long-term viability. CSR is described as a form of representation of company initiatives that have discretionary characteristics with various considerations of criticism from the government and other relevant stakeholders (Matten, 2008). When viewed from another point of view, disclosure of CSR is interpreted as sharing and disseminating information by the company as part of its annual report on matters relating to operations, activities and implementation of certain programs that are considered to affect the public and different stakeholders (Chan, Watson and Woodliff, 2014). According to Nisak and Jaeni (2019), in preparing the company's sustainability report, it refers more to the guidelines from the Global Reporting Initiative (GRI).

The Global Reporting Initiative (GRI) can push entities to be more responsible for a sustainable global economy. GRI also aims to understand and inform business impacts, be it economic, environmental, and social impacts caused by daily activities in the company. Then, to implement sustainable reporting and become standard practice that presents corporate values and governance, shows the relationship between strategies which can then be used to set company goals, and manage change more effectively and efficiently. Regulations regarding awareness of the need to protect the environment and social responsibility in Indonesia have been regulated (Undang-Undang Nomor 40 Tahun 2007 Tentang Perseroan Terbatas ) subsection 74. It is clarified in it that when conducting business practices involving natural resources, social and environmental obligations must be met. In the inside subsection 66 verse 2c UU No. 40 in 2007 it has been explained that all companies are obliged to report the implementation of social and environmental responsibility in the company's annual report. Corporate social responsibility reports are used as a means of corporate communication as well as marketing and promotion media platforms used by companies to make judgments or appropriate stakeholder considerations (Nielsen, 2007).

Corporate social responsibility assumes that the company will convey information for the benefit of the state to be included in its social responsibility plans for society and the environment (Lone, Ali and Khan, 2016). From year to year, the number of companies reporting their social responsibility plans has experienced a large increase (Sekhon and Kathuria, 2019). CSR disclosure practices in Indonesia have received considerable attention. This is motivated by the development of democracy, and society is increasingly critical, and companies have started to demand to provide transparent information on their social activities (Nisak and Jaeni, 2019). Meanwhile, some violations of CSR practices by public companies in Indonesia, for example, PT Adaro Indonesia demanded by the farmers Kabupaten Balangan, Kalimantan Selatan because it is suspected that the water in the Balangan River has been contaminated by waste from coal mining activities. Farmers of keramba owners suffered losses of tens of millions of rupiah because all the dead fish were ready to be harvested. However, according to a spokesman PT Adaro Indonesia Djoko Soesilo stated that his party had received information about this. But PT Adaro Indonesia denied mining waste (Mediaindonesia, 2018).

\section{Literature Review and Hypothesis Development}

Corporate Social Responsibility: CSR is often interpreted as Social and Environmental Responsibility in Indonesia, based on its etymology. However, as of August 16, 2007, CSR in Indonesia is governed by Law Number 40 of 2007 concerning Limited Liability Companies, which replaces Law Number 1 of 1995 concerning Limited Liability Companies, hereinafter abbreviated as UUPT, and CSR is referred to as stipulated in this Law. Article 1 Paragraph 3 reads, "Social and Environmental Responsibility is the Company's commitment to participate in sustainable economic development to improve the quality of life and a beneficial environment, both for the Company itself, the surrounding community, and society in general". According to Lang and Lundholm (1993) described by explaining various kinds of voluntary disclosures in annual reports, the nature of the company is a prediction of the quality of disclosure. Each company is unique, which is different from other companies. Company characteristics that have been studied by previous researchers have a significant impact on the disclosure of CSR reports in annual reports (Amran, Susela, 2008). The diversity of companies that affect CSR reporting in the annual report is government share ownership, foreign ownership, company size, type of industry, profitability. 
Profitability: Profitability is a variable to measure the ability of a company to obtain profits that are pursued, to increase shareholder value. This profitability factor makes management free and flexible in disclosing CSR to shareholders. The greater the disclosure of CSR details, the higher the degree of company profitability (Sembiring, 2005). According to Hackston and Milne (1996), in their study, he shows that there is no substantial connection between profitability and the disclosure of social information. According to Belkaoui and Karpik (1989), the relationship between a company's financial results, in this case, profitability, and the belief that management's social responsibility is the same as the capacity needed to build a productive business are better reflected in the view that management's social responsibility is the same as the capacity required to create a productive company.

Leverage: The level of debt a corporation has is an indication of how reliant it is on creditors to fund its assets. Meanwhile, companies that have a lower level of leverage fund their assets with their capital. The level of company debt can describe the company's financial risk. Since the expenses incurred by companies with such capital structures are higher, companies with a higher leverage ratio will reveal more details (Jensen and Meckling, 1976).

Company Size: Company size is often used to explain various disclosures in a company's annual report. There are several descriptions of the effect firm size has on the quality of expression. This is illustrated by the various empirical studies that have been conducted which result in the effect of total assets almost always being persistent and statistically significant. Hackston and Milne (1996) state that the extractive industry is a high-profile industry. In addition, various disclosures in a company's annual report are explained using company size and leverage. The mining, chemical, and forestry industries should be classified as high-profile industries. Research that fails to show a relationship between the two variables is research conducted by Sembiring (2005) while research that shows a relationship between the two variables (Hackston and Milne, 1996).

Profitability and CSR Disclosure: A company's profitability shows the relationship between profit and the assets or resources used to produce the profit; in other words, profitability is a company's ability to make money over time. The greater the level of social knowledge disclosure, the higher the level of business profitability. In a company, profitability is a factor that enables management to be more innovative and flexible in communicating social responsibility to shareholders, the higher the level of profitability, the more social information is revealed. The hypothesis can be formulated as follows based on the above explanation: H1: Profitability has an effect on CSR disclosure.

Leverage and CSR Disclosure: Companies that have a high leverage ratio value can disclose broader social responsibility. For this reason, companies with high debt levels may disclose more information to meet their creditors' information needs. This argument can be related to stakeholder theory, which states that a company's survival is heavily influenced by the help provided by its stakeholders, companies with a high degree of control will disclose more details to their stakeholders in order to eliminate doubts and increase confidence in the company's ability.

H2: Leverage has an effect on CSR disclosure.

Company Size and CSR Disclosure: The legitimacy theory states that large-scale firms can carry out more operations, resulting in a greater impact on society and the environment. The effect of business size on CSR disclosure carried out by the company can also be attributed to the legitimacy theory, which states that largescale companies can carry out more activities, resulting in a greater impact on society and the environment. The support provided to a business by stakeholders has a significant impact on its life. This is because the operation of this sector from the beginning to the completion of the use of natural resources can have a significant impact on environmental damage. It has been proven from the phenomena that occur in companies in the mining sector. Furthermore, this analysis used a sample of 160 companies that are listed on the Indonesia Stock Exchange. Furthermore, data analysis in this study was proposed using multiple regression analysis. However, large corporations now have more stakeholders that are interested in the company's social services. Related to stakeholder theory, companies with a larger size will disclose more CSR information to stakeholders as a means of communication to maintain good relations and meet stakeholder expectations (Wardhani and Muid, 2017). This study supports that of Widiastuti et al. (2018), who found 
empirical evidence that company size has a positive impact. The hypothesis, based on the above explanation, can be summarized as follows:

H3: Company size has an effect on CSR disclosure.

Figure 1: Research Framework

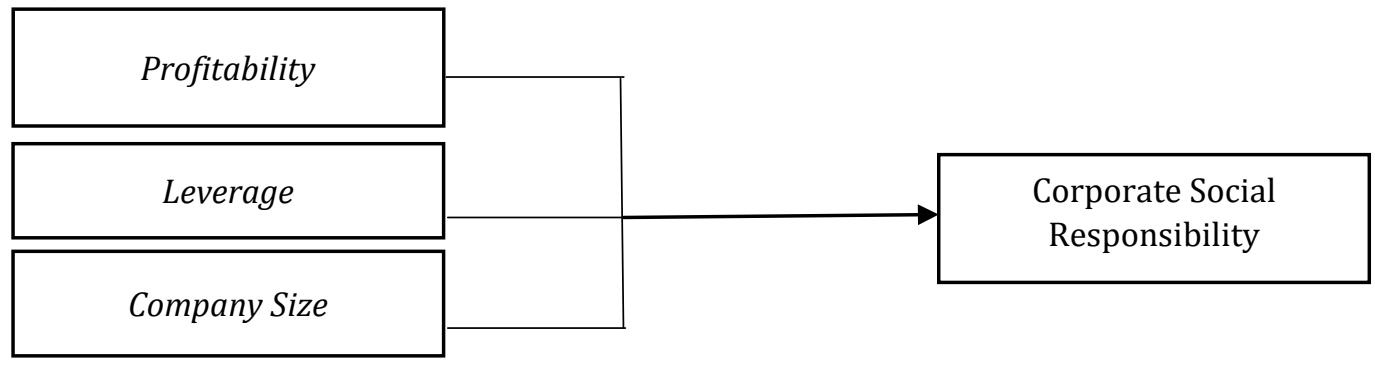

\section{Proposed Method}

The population is the object of research to be studied and is also a collection or aggregation of all elements or individuals who become the source of research information. According to the population, a general area consists of items or topics with specific qualities and characteristics that the researcher has defined and concluded for analysis. From 2017 to2019, the population for this study was mining sector companies listed on the Indonesia Stock Exchange. Mining companies were chosen because they had long been the center and main pillar of Indonesia's economic expansion, which contributed significantly to the country's GDP through profitable exports. However, on the other hand, the mining sector is getting enough attention from stakeholders.

\section{Conclusion and recommendations}

This study's conceptual paper aims to look into the factors that influence corporate social responsibility on the Indonesia Stock Exchange. This is significant because management who is conscious of and concerned about social issues would increase the skills required to improve a company's financial results. The risk is that those who receive a social reaction to social responsibility disclosure are forced to fire someone who does not adjust to the influence between business profitability and accounting variables such as investment returns and market variables such as stock price differential returns. Large corporations are business entities that become important, greater disclosure represents the cost of politics as a social responsibility. This result is expected the three hypotheses are significantly and positively influences the corporate social responsibility disclosure. The findings of this study are expected to contribute significantly to investors it is expected to help investors to identify the state of the company based on corporate social responsibility by looking at factors such as profitability, leverage and company size performed by the company in terms of knowing how the influence of these factors can improve the company in implementing CSR. In addition, the company's ability to improve its social obligation to the environment and other stakeholders is recommended.

\section{References}

Amran, A. \& Susela, D. S. (2008). The Impact of Government and Foreign Affiliate Influence on Corporation Social Reporting (The Case of Malaysia). Accounting, Auditing, and Accounting Journal, 23(4), 386404.

Belkaoui, A. \& Karpik, P. G. (1989). Determinants of the Corporate Decision to Disclose Social. Auditing and Accountability Journal, 2(1), 36-51.

Chan, M. C., Watson, J. \& Woodliff, D. (2014). Corporate governance quality and CSR disclosures. Journal of Business Ethics, 125, 59-73.

Friedman, M. (1962). Capitalism and Freedom. Chicago: United States: University of Chicago Press.

Gray, R., Owen, D. \& Maunders, K. (1987). Corporate Social Reporting: Accounting and Accountability. London: Prentice-Hall. 
Hackston, D. \& Milne, M. J. (1996). Some Determinants of Social and Environment Disclosures in New Zealand Companies. Accounting, Audit \& Accountability Journal, 9(1), 77-108.

Jensen, M. C. \& Meckling, W. H. (1976). Theory of the firm: Managerial behavior, agency cost, and ownership structure. Journal of Finance Economics, 3(4), 305-360.

Lang, M. \& Lundholm, R. (1993). Cross-Sectional Determinants of. Analyst Ratings of Corporate Disclosures. Journal of Accounting Research, 31(2), 246-271.

Lone, E. J., Ali, A. \& Khan, I. (2016). Corporate governance and corporate social responsibility disclosure: evidence from Pakistan. Corporate Governance, 16(5), 785-797.

Matten, A. C. (2008). Editor's introduction. Corporate social responsibility as a field of scholarship. London: Sage Publication.

Mediaindonesia. (2018, May 21). Limbah Adaro Diduga Cemari Sungai. Retrieved from https://mediaindonesia.com/nusantara/162086/limbah-adaro-diduga-cemari-sungai

Nielsen, A. E. \& Thomsen, C. (2007). Reporting CSR-what and how to say it? Corporate Communication: $A n$ International Journal, 12(1), 25-40.

Nielsen, A. C. (2007). Survey of Consumer Behavior and Perception toward Modern Retail and Traditional Trade Channels. Jakarta: Departemen Perdagangan Indonesia.

Nisak, K. \& Jaeni, J. (2019). Faktor Penentu Pengungkapan Corporate Social Responsibility. Dinamika Akuntani, Keuangan, dan Perbankan, 8(1), 37-51.

Nurkhin, A. (2010). Corporate Governance dan Profitabilitas, Pengaruhnya Terhadap Pengungkapan CSR Sosial Perusahan. Journal Dinamika Akuntansi, 2(1), 46-55.

Podnar, K. \& Golob, U. (2007). Corporate Social Responsibility expectations: The Focus of Corporate Marketing. An International Journal, 12(4), 57-72.

Rahman, H. W. A., Zain, M. M. \& Al-Haj, N. M. (2011). CSR disclosures and its determinants: evidence from Malaysian government link companies. Social Responsibility Journal, 7(2), 181-201.

Respati, R. D. \& Hadiprajitno, P. B. (2015). Analisis Pengaruh Profitabilitas, Leverage, Ukuranperusahaan, Tipe Industri, Dan Pengungkapan Media Terhadap Pengungkapan Corporate Social Responsibility. Diponegoro Journal of Accounting, 4(4), 1-11.

Salehi, M., Tarighi, H. \& Rezanezhad, M. (2019). Empirical study on the effective factors of social responsibility disclosure of Iranian companies. Journal of Asian Business and Economic Studies, 26(1), 34-55.

Sekhon, A. K. \& Kathuria, L. M. (2019). Analyzing the corporate social responsibility disclosures of selected companies in India. Corporate Communication: An International Journal, 24(4), 696-701.

Sembiring, E. R. (2005). Karakteristik Perusahaan dan Pengungkapan Tanggung Jawab Sosial: Studi Empiris Pada Perusahan yang Tercatat di Bursa Efek Jakarta. Simposium Nasional Akuntansi, 7, 69-85.

Thomson, P. \& Zakaria, Z. (2004). Corporate social responsibility reporting in Malaysia progress and prospects. Journal of Corporate Citizenship, 13, 125-136.

Undang-Undang Nomor 40 Tahun 2007 Tentang Perseroan Terbatas. (n.d.). http://bapepam.go.id/r eksadana/files/r egulasi/UU402007PerseroanTerbatas.pdf.

Wardhani, R. A. \& Muid, D. (2017). Pengaruh Agresivitas Pajak, Ukuran Perusahaan, dan Profitabilitas Terhadap Corporate Social Responsibility: Studi Empiris Pada Perusahaan Manufaktur yang terdaftar di BEI Tahun 2014-2015. Diponegoro Journal of Accounting, 6(3), 752-761.

Widiastuti, H., Utami, E. R. \& Handoko, R. (2018). Pengaruh Ukuran Perusahaan, Tipe Industri, Growth, dan Media Exposure Terhadap Pengungkapan Tanggung Jawab Sosial Perusahaan: Studi Empiris Pada Perusahaan yang Terdaftar di BEI Tahun 2015. Riset Akuntansi dan Keuangan Indonesia, 3(2), 107 117. 